\title{
EVALUATING INTERCULTURAL AWARENESS RAISING IN TWO ESTONIAN EFL SECONDARY SCHOOL TEXTBOOKS
}

\author{
Liljana Skopinskaja, Suliko Liiv, \\ Regina Beilmann, Raimond Virsa \\ Tallinn University
}

\begin{abstract}
Nowadays teachers have rarely an opportunity to work within a monocultural context, and rather than teach English, they have to sensitize students to the cultural component of a multitude of Englishes as well as students' own cultures. Much of this information is derived from coursebooks. The article tries to fill the gap in the literature in the field of coursebook evaluation in Estonia by analysing intercultural awareness raising in the two local and global EFL coursebooks currently employed in Estonian upper secondary schools. We use a qualitative study with methods of textual analysis to examine how authors introduce interculturality in textbooks. Our findings show that what the coursebooks claim to be providing may not necessarily be what is delivered.
\end{abstract}

Keywords: culture-and-language instruction, local and global coursebooks, Estonian upper secondary school level, English as a foreign language

\section{Introduction}

Among other aspects of general competencies, cultural and value judgemental competence is deemed essential in the Estonian National Curriculum. It is emphasized that language command is a vital segment of one's identity, but being tolerant of and respectful towards the languages and cultures of other nationalities is of paramount importance in the contemporary multicultural world. School-leavers should become functioning members of society who do not have a biased and prejudiced world view but instead 
acknowledge that there is a variety of people, with their own outlooks and communication situations (Education Act 2016).

When learning a foreign language, acculturation takes place in some general or specific form. In addition to the new linguistic means of communication being acquired, varied social contexts for their practical application are also being developed. Acculturation is a dual process of cultural and psychological change that takes place as a result of contact between two or more cultural groups or sets of information about different ways of life, social structures, and values. Cultural transmission is usually offered by selected content and organised learning. Culture learning (in EFL lessons) refers to the process of the acquisition of features of a new culture in which acculturation contexts and strategies play a crucial role (Berry 2008: 546-552).

In recent years, much attention has been given to the essence of intercultural communicative competence (Byram 2012, Deardorff 2006), which may be defined as the skill to act as a mediator between one's own and other cultures (Coyle 2009: 108). It comprises the development of a person's declarative intercultural knowledge (savoirs), skills (savoir-faire), and existential competence (savoir-être), where savoirs refers to the knowledge of the world, of the diversity of ways of living, as well as the knowledge of the cultures of the communities in which the target language is spoken; savoir-faire to people's ability to use a variety of strategies to contact with those from other cultures, the capacity to overcome one's stereotyped attitudes and to fulfil the role of a cultural intermediary; and savoir-être is characterized by attitudes, values, beliefs, cognitive styles and personality linked to one's personal identity, enabling people to understand and interpret other cultures from their point of view (Lussier et al. 2007).

We cannot but agree with Sleeter and Grant when they stated that the textbook is "the major conveyor of the curriculum" (Sleeter, Grant 2011: 186). The plethora of English-language materials, both global textbooks and local ones, available in Estonia to choose from, 
may give the EFL teacher a sense of being able to meet the needs of contemporary language-and-culture instruction; however, many of these textbooks (especially global ones) have necessarily not been designed with the requirements of the Estonian National Curriculum in mind and may lack important sociocultural information used for raising EFL students' intercultural awareness. Or language teachers may focus their instruction on linguistic competence only and ignore the sociocultural topics contained in their teaching materials. Given the increasing international discussion about what constitutes acceptable EFL content and what facilitates intercultural awareness (Ahmed, Narcy-Combes 2011, Risager 2014, Hahl et al 2015), the present article seeks to analyse the development of intercultural communicative competence of EFL learners at upper secondary school level by evaluating two locally produced (Estonian) and global/international coursebooks, namely: All the World's a Puzzle. Form 10 by Merike Saar and Meeri Sild, and Activate B1+ Students Book by Carolyn Barralough and Megan Roderick. The choice of the aforementioned coursebooks is based upon previous research conducted in foreign language education in the field of coursebook evaluation. Two types of studies dominate this field: research on the representations of Self and Other, and the development of intercultural (communicative) competence (Dervin et al. 2015: 153). As to the first category, Shin et al. (2011) have explored the presentation of local and international culture in internationally-produced textbooks and their study shows that Western cultural content dominates this field. A similar conclusion has been reached by other scholars (Sercu 2000, Yakhontova 2001, Skopinskaja 2003, Walters 2009, Yamada 2010, 2011, Beilmann 2012, Virsa 2016). In Walters' and Rossner's words, international coursebooks reflect insufficiently the needs of school learners because of "lack of personalization and the cultural bias of their content and methodology" (Walters 2009: 313) since they foster "values and educational attitudes which are intrinsically Western and mainly Anglo-Saxon" (Rossner 1988: 160). In terms of the development of intercultural competence, Nguyen's (2011) and 
Arao and Kimura's (2014) research may be highlighted, where the former analyses the development of intercultural pragmatic competence in textbooks while the latter investigate the selection of topics in terms of developing learners' mutual understanding.

Another reason for the selection of those coursebooks is determined by a general situation of coursebook selection policy in Estonian secondary schools. Due to financial circumstances, schools may choose between local or international coursebooks, and since upper secondary school EFL lessons are mostly catering for the preparation of students for the national examination in English, school authorities tend to select textbooks like Activate B1+Students' Book which have been designed with this particular purpose in mind. In our analysis, we try to combine both approaches by exploring whether there are any differences between local and international coursebooks (which are being currently employed by Estonian schools) in terms of Self and Other representations and whether all aspects of intercultural communicative competence (i.e. knowledge, skills, attitudes) are being tackled therein.

\section{Theoretical Background}

\section{I. CONCEPTS OF CULTURE AND LANGUAGE}

There is no doubt that the study of language should be combined with a study of culture. Language teaching and learning is not only concerned with teaching vocabulary, grammar, and increasing the student's communicative ability; there are three additional aspects to concentrate upon: language use, awareness of the nature of language, and understanding of foreign and native culture (Byram 1989:23). Language and culture are bound, interwoven and inseparable.

The term "culture" originally comes "from the Latin word 'colere" which means "to cultivate" as opposed to "'nascere' [...] 'to be born"” (Kramsch 1998:8). This kind of dichotomy sees "nature" as "what is born and grows organically" whereas "culture refers to what has been grown and groomed. [...] The word culture evokes 
[the] nature/nurture debate: are human beings mainly what nature determines them to be from birth or what culture enables them to become through socialisation and schooling?" (ibid.). During the time the Latin terms were coined, there was neither science in the sense that it existed after the Enlightenment, positivism, industrial revolution and other changes in Western civilisation, nor did they have the research technology and methods, humankind possesses today. That is one reason why dividing nature and culture into opposite poles is rather questionable, and finding one "correct" definition is even harder. Moreover, since the nature/nurture debate has not reached one generally accepted conclusion in scientific circles, both over-definition and oversimplification are likely to fuel rather than to lessen the debate. Still, it is problematic to discuss teaching or learning culture by leaving the notion in question aside completely. One solution to the problem would be putting the nature/nurture dichotomy to the side, viewing culture as processes and products that are connected to humans and different groups that they tend to form (Virsa 2016:16).

Culture can be viewed as knowledge of the texts and practices of a certain community as well as its members' awareness of themselves and their identity in that culture. In addition, the notion is often described as an understanding and recreation of individuals' meanings in everyday activities in order to satisfy their needs and maintain their position. Culture may also be defined as critical thinking about itself, investigating how its main practices, theories, beliefs, values, implications, renditions and artefacts have come to be viewed as natural, normal and objective reality and whose interests the dominant elements are serving. Moreover, since most aspects of culture are eventually seen as constructed (often arbitrary) and the competing subcultural groups have different agendas, culture comes across as a verb-like notion, struggling for power and constantly changing.

Recent developments in linguistic, cultural and pedagogical studies do not tend to view language and culture as separate aspects 
of study. According to Cunningsworth (1995), a "study of language as solely an abstract system would not equip learners to use it in the real world" (p. 86). Language, which is, in most cases, a symbolic arbitrary system of signs, needs a system of shared meanings so that participants of a communication process would understand each other to the extent that the purposes of communication could be achieved.

Accordingly, one of the central functions of language is aiding individuals to communicate their messages to others as well as decoding the incoming information. In order to achieve mutual understanding, interlocutors need to have a shared framework of discourses, meanings and values. Communication is "always a cultural process and communicating [...] involves establishing relationships between one's own and other cultures", be it between representatives of subcultures of a nation or individuals from different civilisations (Roberts, Byram et al 2001: 7).

The function of being a device of communication for different groups is closely connected to culture being a site of competition and conflict. Different countries as well as social classes and individuals are in a constant struggle for power and influence, which includes establishing their values, beliefs and explanations as the dominant ones or maintaining their current position in the hierarchy. Byram (1997: 7-8) refers to Hymes who writes that humans need to "pay attention to the way in which not only grammatical competence but also the ability to use language appropriately is required". Choosing the right style, register, vocabulary, intonation and other nonverbal features of communication plays an integral role in influencing people and gaining or maintaining status.

To conclude, language as an abstract system of exchanging information needs a background or a context of shared meanings to be used efficiently in communication. On the other hand, culture, as a site of struggle, requires the organising qualities of language for its carriers' maintenance of identity and competition for dominance (Virsa 2016: 17). 


\subsection{CULTURE AND FOREIGN LANGUAGE TEACHING}

Byram and Morgan maintain in Teaching and Learning Language and Culture that language (and inevitably culture) teaching "has a significant role in developing young people's critical awareness of their own and other societies and moving them into more advanced thinking as citizens with political understanding" (Byram, Morgan 1994: 3). As learners adopt different perspectives on the ways of reaching goals to satisfy their needs, they are able to see their own culture from multiple viewpoints. This enables them to adopt and develop their native culture further as well as tolerate the Otherness since they are less likely to see their own belief and value system as absolute truth and as being the best solution to the various challenges we face in the world today.

Contemporary language learning theories have adopted the notions "script" and "schema", "widely used in social psychology and aspects of discourse analysis", to describe the process of learning to function and achieve goals in one's own or another culture acculturation (Roberts et al 2001: 40). Scripts refer to the knowledge of managing one's everyday practices entailing the skills and knowledge that are "internalised as part of our own socialisation" (ibid.). Schema may be viewed as "networks of cultural references", which enable learners to understand texts of a certain culture (ibid.). Learners tend to acquire these schemas first in their native language and then in the second and subsequent language(s) as part of their primary, secondary and tertiary socialisation (ibid.). Primary socialisation entails learning to use language in "specific interactional sequences", and becoming communicatively competent in the foreign language, whereas secondary socialisation refers to acquiring "institutional practices of schooling and schooled ways of knowing things" (Roberts et al 2001: 10). Tertiary socialisation is viewed as a process of "entering into the social practices of the foreign language community" (ibid.) and becoming aware of what is different and unfamiliar in the social worlds encountered. 
Foreign language teaching initiates "the learners to the values of a foreign culture, while at the same time helping them not to be bound in either one" (Kramsch 1993: 256-7). By adopting schemas of different cultures, learners are more likely to comprehend that there are various equally effective strategies to achieve a high quality of living. Furthermore, the capacity of different groups to enrich each other rather than being a potential threat tends to become more evident.

\section{Coursebook Evaluation Criteria}

It is evident that EFL coursebooks are never neutral in terms of their cultural content. Cunningsworth (1995) is convinced that if coursebooks have any subject content they will communicate sets of social and cultural value either directly or indirectly. This is the so-called "hidden curriculum", which forms part of any educational programme, but is unstated and undisclosed. It may well be an expression of attitudes and values that are consciously held but which nevertheless influence the content and image of the teaching material, and indeed the whole curriculum (p. 90).

Many educationalists state that the hidden curriculum is more effective than the official curriculum. Risager (2014) is of the opinion that foreign language teaching materials increasingly participate in the general cultural transmission with the educational system and the rest of society.

Ideally, teaching materials, including coursebooks, should depict social realities accurately and in an unbiased manner. However, the methodologies involved in coursebook design may be ethnocentric, not in terms of national cultures, but in terms of groups of teachers or political interest groups who are either using or creating them (Holliday 2005: 90). Holliday views these methodologies as constructions on reality created to satisfy the needs of the professionalacademic cultures of teacher groups. The author states that " $[\mathrm{t}] \mathrm{hey}$ represent paradigms which provide these cultures with recipes for 
action, rather than scientific paradigms provide recipes for action for scientific groups" (ibid.).

Since the underlying value system is often implicitly represented in teaching materials, the latter deserve a more detailed analysis to understand the hidden values implied, and it is this that coursebook evaluation should be directed at.

Coursebook evaluation is a complex procedure as it demands the assessment of the content of a body of teaching material in relation to its professed aims and objectives as well as learner needs and interests; the coverage of a variety of cultural topics; the extent to which the goal of cultural instruction is stated (whether it is primary or subordinate to other goals); and the presentation of the cultural content in context or as isolated facts (Skopinskaja 2003: 60). Selecting a suitable EFL textbook should ideally be carried out according to certain criteria, but in reality teachers may find coursebook evaluation too time-consuming or the concept of evaluation may be unknown to them. This may result in unjustified decisions that have a negative influence on a school's budget or, even more problematic, the quality of teaching and learning. Another issue in the evaluation of materials is that research has mostly been concerned with pre-use evaluation, which is speculative and often time consuming for teachers to use. There is a clear demand for in-use and post-use evaluation. This indicates that evaluation of materials should be considered as an on-going process.

The existing literature on textbook evaluation offers a variety of checklists of evaluation criteria for cultural content. Since evaluation of materials is considered to be a relatively subjective area, the checklists often reflect the researchers' views about what criteria are measured and valued in a coursebook (Tomlinson 2003: 27-33). Among the cultural issues emphasized are: educational/social acceptability of textbook approach to the target community (Ur 2005: 186), possible stereotypes of races and cultures (Harmer 2007: 154), and teaching either English as a foreign language (EFL) or English as an international language (EIL), which Englishes to teach, which cultures to 
teach, usage by native English speakers or non-native English speakers, relationships with English in EFL or EIL contexts, and development of intercultural communicative competence (Mishan, Timmis 2015: 41). Sheldon's (1988) list evaluates the coursebook's appropriateness, authenticity and cultural bias (p. 244). Damen (1987) examines the historical dimension, the presence of evaluative comment, either direct or implied, underlying the cultural content, as well as the development of intercultural communicative skills (pp. 272276). Byram's criteria (1994: 51-52) focus on the inclusion of social identity and interaction, socio-political institutions, socialisation and the life cycle, national history, geography and cultural heritage, and symbols of national stereotypes. Cunningsworth's (1995: 92) checklist for socio-cultural values in textbooks focuses on the interpretation of cultural contexts. He claims that a curriculum, and the teaching forms part of this, can never be entirely neutral because it has to reflect a view of social order and express a value system, and therefore the evaluation of underlying values in EFL coursebooks is at least as important as that of language content or methodology employed because the value system entailed in the coursebook can influence the perceptions and attitudes of learners generally and towards learning English in particular (Cunningsworth 1995: 90). He proposes evaluating sociocultural values of coursebooks according to the following criteria: 1) range of topics; 2) inclusion of sensitive socio-cultural topics; 3 ) characters depicted: a) representation of women, b) portrayal of gender roles, c) age, d) social class, e) ethnic origin, f) occupation/profession, g) disability; 4) social relationships: a) family make-up, b) social networks; 5) expression of personal feelings; 6) interactions: a) transactions, i.e. functional interactions, b) personal interactions (p. 92). Risager's (2014) coursebook evaluation captures the essence of the aforementioned Cunningsworth's checklist in a nutshell by distinguishing between the three types of coursebook evaluation: 1) thematic approach, where culture is regarded as a large amount of various topics in relation to everyday life, history, geography, society; and culture learning is 
viewed as the acquisition of facts about the target language community; 2) intercultural analysis, where culture is tackled as a diversity of various perspectives of individuals and groups, their types of knowledge about the world by virtue of their different life experiences; and culture learning refers to the development of learner awareness about socio-cultural perspectives and identities, such as empathy, cooperation and conflict resolution; 3) and power and empowerment analysis, where culture is seen in terms of conflicts and ideologies and cultural learning entails the development of learners' ability to reflect on and understand major political and social issues, thereby contributing to their development as world citizens. Our evaluation of EFL coursebooks currently employed by Estonian upper secondary school learners will be based on the first two aspects of Risager's tripartite classification, since the EFL teaching materials (currently utilised in Estonian secondary schools) may lack a comprehensive overview of any major political or social aspects in their structure as the main focus of EFL instruction is still on communicative competence rather than power and empowerment issues.

\section{Evaluation of the Coursebooks Activate BI+ Students' Book and All the World's a Puzzle. Form 10}

Two coursebooks, locally produced textbook All the World's a Puzzle. Form 10 by Merike Saar and Meeri Sild and global textbook Activate B1+ Students' Book by Carolyn Barralough and Megan Roderick have been chosen for the evaluation in regard to their coverage of cultural topics, representation of socio-cultural values and socio-political issues. Our aim is to establish what kind of cultural topics are represented, what kind of socio-cultural values as well as socio-political issues are discussed in the two coursebooks and how well student awareness is raised of what is different, unfamiliar or similar in the social world around them, i.e. how well their schemata are being activated. The material employed for the analysis 
comprises reading texts, listening passages, exercises (if presenting cultural information), songs, lyrics, photos and drawings and advertisements available in both coursebooks.

\section{I. THEMATIC APPROACH}

The structure of the local coursebook All the World's a Puzzle. Form 10 is based on the requirements of the Estonian National Curriculum and accordingly comprises four chapters: Chapter I - The World We Live In; Chapter II - Social Environment; Chapter III - Natural Environment; and Chapter IV - Consumer Society. The chapters are further divided into three or four units and the topics discussed are varied. For example, the first chapter in Form 10 focuses on the geography, economy and nature of English-speaking countries. It is noteworthy that besides the UK and the USA, some information about Ireland, Canada, South Africa, Australia and New Zealand has also been offered. Chapter II involves topics about social environment and the students are introduced to the notions of personal development, multicultural society and business relations. The value of the last topic is debatable as it mostly considers the business strategies and annual reports of companies, which teenagers may find hard to relate to. Chapter III is devoted to the natural environment and students learn about housing, traffic, tourism and the concept of ecological footprint. The topics here are interesting and go beyond the conventional range of subjects. For example, tourism is tackled with the example of Tallinn instead of London, the latter of which is over-presented in coursebooks and may add to the stereotypical depiction of the target language culture. Chapter IV discusses pop music, services with a focus on shopping, fashion, holidays and travelling. All the topics discuss the phenomena that teenagers feel at home with, offering them opportunities to express their opinions and views. In addition to texts, a lot of cultural input is presented through photos, drawings, maps, etc. 
The international coursebook Activate B1+Students' Book claims to be ideal for students preparing for international examinations by offering various themes from contemporary teen culture. The book contains texts about celebrities from sports, pop music (e.g. Justin Timberlake, Cristiano Ronaldo, etc.), various Hollywood films (e.g. Star Wars and Lord of the Rings), TV series (the British TV series Doctor Who) and reality shows (the TV programme Rock School hosted by Gene Simmons), thus focusing on those aspects of culture that teenagers can most easily relate to. There are a few texts devoted to more serious issues, such as environmental protection ( $\mathrm{p}$. 84), anger management (p. 75), and a web page Matmice created by teenagers in order "to share their experiences and learn from other children" (p. 85) and support each other with different problems, but the overall tendency in this coursebook is to avoid more serious issues like racism, discrimination and unemployment. The textbook seems to imply that there is one single teen culture enjoyable and interesting to all teenagers, with no alternative cultural realities being offered for comparison and contrast. In addition, the focus is predominantly on Anglo-American culture, with only three countries being represented - the UK, the USA and Australia. Thus we may conclude that the present international coursebook is more restricted in its coverage of cultural topics compared to the locallyproduced textbook.

\subsection{INTERCULTURAL ANALYSIS}

Sensitive socio-cultural topics are dealt with in the units of Chapter II of the locally produced coursebook All the World's a Puzzle: Form 10, which is designed to present such issues of the social environment as marital strains, domestic violence, child abuse, depression, racism and substance abuse as being prevalent in society. These topics are not treated in depth, but they appear in various reading texts, listening tasks and translation exercises. For example, there is a reading text about Dr. Phil McGraw which deals with problems 
of personal development. The text is accompanied by a pair work assignment in which students have to discuss in pairs questions like: what problems they have noticed in the society, why people access counselling services, what might a recipe for happy life be, or even personal questions such as whether they have ever encountered similar problems and how they have managed to solve them. In connection with a reading text about fashion in Unit 3 of Chapter IV, there is a translation exercise devoted to eating disorders like anorexia and bulimia.

As to the coverage of sensitive socio-cultural issues in the international coursebook Activate B1+Students' Book, there are a few like a reading text about three sisters from Australia who created a website enabling "children to share their experiences and learn from other children with different backgrounds" (p. 129). The text introduces the interactive nature of the website as well as the problems children may face when starting to use ICT to create similar internet pages. Furthermore, there is a small extract (no. 7) called "The Unteachables", in which a teenager talks about his lack of interest in episodes of anger and violence. He explains: "I get into trouble" (01:42), "And one more stretch of that like suspensions" (01:44), "Like if I get suspended one more time I'm out" (01:47). The narrator continues with the story: "With his confidence boosted" (01:50), "He is now fully participating in lessons for the first time ever" (01:53). There is one more narrative about a student with psychological and social problems who achieved social success, i.e. an ability to participate in school work after having dealt with his psychological problems (relating to lack of self-esteem) in a special program meant for teenagers with learning difficulties.

Thus it may be concluded that sensitive socio-cultural issues have been given sufficient prominence in the locally-produced coursebook, so that they do not appear as mere tokens. Some scholars argue that the inclusion of such topics may traumatise students, and that they should, therefore, be avoided in language materials. Gray (2002) warns against using certain topics (e.g. politics, 
alcohol, religion, sex, narcotics, -isms, pork) because they may be perceived as offensive. Wallace (2002) argues, on the contrary, that restricted exposure of learners to safe content and topics may in fact be demotivating as it reduces levels of engagement, which has linguistic repercussions. The DVD for the international coursebook Activate B1+Students' Book includes an extract for Chapter One "I Like Your Style" which is illustrative of the tendencies mentioned by Wallace above. The protagonist of the reading chapter "Look Good, Feel Good" is Alexandria, "a 15-year-old schoolgirl" who "was the subject of a TV programme, Family Fashion" (p. 9). Before the makeover by the reality show, Alexandria preferred wearing "baggy tracksuits, T-shirts and some denim jeans". The images of her wearing the clothes of her own choice in the show on the DVD clip are accompanied by dissonant music typical of horror movies and the text in the coursebook includes an evaluative comment from Jane, the stylist: "There is not a skirt in sight!". On the clip, the stylists add some more "feminine" characteristics to Alexandria's style and as a result, in "her skirts, fancy tops and heels with a new funky hairstyle" the protagonist "looks confident and happy". Now she "could be a professional model!" In such a way, the cultural content of this coursebook is reduced to the level of the 3 Ds of consumerist society: dinner parties, dieting and dating (Wallace 2002: 109). The coursebook authors seem to imply that there is only one teen culture associated with the icons of contemporary entertainment industry, thus virtually ignoring the multitude of teen subcultures around the world as well as the plurality of teenagers' social and cultural identities in order to promote mainstream culture created by AngloAmerican entertainment industries.

\section{Conclusion}

The present article was an attempt to analyse one locally produced coursebook, All the World's a Puzzle, and a global coursebook, Activate B1+Students' Book, in terms of intercultural awareness raising 
input. The books were evaluated on the basis of Risager's checklist for identifying particular cultural topics (thematic approach) and developing students' awareness of various socio-cultural values and identities (intercultural analysis) in the selected coursebooks. The amount of the material offered for the development of the students' intercultural awareness is rather impressive in the local coursebook and remains quite meagre in the international one, as the strategies employed in the latter result in a trivial treatment of most of the topics discussed, avoidance of sensitive socio-cultural issues and promotion of the policies of Anglo-American entertainment industries. The most positive side of the former, however, is the diversity of the content and that of the methodological devices employed for the presentation of the material. The local coursebook has a broad range of topics that are treated sufficiently thoroughly so as not to promote stereotyping or provide generalisations of the subject area. Sensitive socio-cultural topics are mostly included in the local coursebook, but there are some issues that need to be addressed additionally, like the representation of different social classes and ethnicities in Estonia. Although both coursebooks intend to prepare students for taking final examinations in English, it is regrettable that the major focus of the global coursebook still remains on linguistic competence rather than on the development of intercultural communicative competence, which is presented as something additional in this coursebook.

The abovementioned does not pretend to be a thorough analysis of the status of intercultural awareness raising in the EFL coursebooks used in Estonian upper secondary schools since it is based on the evaluation of only two coursebooks, but the findings of our research suggest that this subject area deserves further investigation as well as more elaborate research methodology in order to encourage a more successful selection and utilisation of EFL teaching materials in the future. 


\section{REFERENCES}

Ahmed, Fasih; Marie F. Narcy-Combes 2011. An analysis of textbook from a cultural point of view. - TESOL Journal 5, 21-37.

Arao, Hiroko; Maiko Kimura 2014. A study of topics in English textbooks for mutual understanding. - Linguistics, Culture \& Education, vol. 2014, article ID1.

Barralough, Carolyn; Megan Roderick 2008. Activate! B1+ Students' Book. Harlow: Pearson Education.

Beilmann, Regina 2012. Social and Cultural Values in the Coursebook Set "All the World's a Puzzle". MA thesis. Tallinn: Tallinn University.

Berry, John W. 2008. Acculturation. - Handbook of Socialisation: Theory and Research. Eds. Joan E. Grusec, Paul D. Hastings. New York: Guilford, 543-558.

Byram, Michael 1997. Teaching and Assessing Intercultural Communicative Competence. Clevedon: Multilingual Matters.

Byram, Michael; Carol Morgan and Colleagues 1994. Teaching and Learning Language-and-Culture. Clevedon: Multilingual Matters.

Byram, Michael 1989. Cultural Studies in Foreign Language Education. Clevedon: Multilingual Matters.

Byram, Michael 2012. Conceptualizing intercultural (communicative) competence and intercultural citizenship. - The Routledge Handbook of Language and Intercultural Communication. Ed. Janet Jackson. London \& New York: Routledge, 85-97.

Coyle, Do 2009. Promoting cultural diversity though intercultural understanding: a case study of CLIL teacher professional development at in-service and pre-service levels. - Content and Language Integrated Learning: Cultural Diversity. Ed Maria Luisa Carrio-Pastor. Bern; Peter Lang, 105-124.

Cunningsworth, Alan 1995. Choosing Your Coursebook. Oxford: Heinemann.

Damen, Louise 1987. Culture Learning: The Fifth Dimension in the Language Classroom. Reading, Mass.: Addison-Wesley.

Deardorff, Darla K. (ed.) 2009. The SAGE Handbook of Intercultural Competence. Thousand Oakes, CA: SAGE.

Dervin, Fred; Kaisa Hahl; Anu Härkonen; Heidi Layne 2015. "Do I contradict myself? Very well, I contradict myself (...)”: representing intercul- 
tural encounters in two Finnish history textbooks. - Diversities and Interculturality in Textbooks: Finland as an Example. Eds. Kaisa Hahl, Pia-Maria Niemi, Rita Johnson Longfor, Fred Dervin. Cambridge: Cambridge Scholars Publishing, 149-173.

Education Act 2016. Riigiteataja, 2016, https://www.riigiteataja.ee/akt/ 123032015254 (28.09.2018).

Gray, John 2002. The global coursebook in English language teaching. Globalisation and Language Teaching. Eds. David Block, Deborah Cameron. London: Routledge, 151-167.

Hahl, Kaisa; Pia-Maria Niemi; Rita Johnson Longfor; Fred Dervin (eds.) 2015. Diversities and Interculturality in Textbooks: Finland as an Example. Cambridge: Cambridge Scholars Publishing.

Harmer, Jeremy 2007. How to Teach English. New ed. Harlow, Essex: Pearson Longman.

Holliday, Adrian 2005. The Struggle to Teach English as an International Language. Oxford: Oxford University Press.

Kramsch, Claire 1993. Context and Culture in Language Teaching. Oxford: Oxford University Press.

Kramsch, Claire 1998. Language and Culture. Oxford: Oxford University Press.

Lussier, Denise; Ksena Golubina; Daniel Ivanus; Guadalupe de la Maya Retamar; Liljana Skopinskaja; Silvia Wiesinger 2007. Guidelines for the assessment of intercultural communicative competence (ICC). Developing and Assessing Intercultural Communicative Competence: A Guide for Language Teachers and Educators. Eds Ildikó Lázár, Martina Huber-Kiegler, Denise Lussier, Gabriela S. Matei, Christiane Peck. Strasbourg/Graz: Council of Europe Publishing/ECML, 23-40.

Mishan, Freda; Ivor Timmis 2015. Materials Development for TESOL. Edinburg: Edinburg University Press.

Nguyen, Minh Thi Thuy 2011. Learning to communicate in a globalised world: to what extent do school textbooks facilitate the development of intercultural pragmatic competence? - RELC Journal, 42, 1, 17-30.

Risager, Karen 2014. Analysing culture in learning materials. - Sprogforum 59, 78-86. https://unipress.dk/media/3583814/sprogforum_59_risager. pdf (12.04.2018) 
Roberts, Celia; Michael Byram; Ana Barro; Shirley Jordan; Brian V. Street 2001. Language Learners as Ethnographers. Clevedon: Multilingual Matters.

Rossner, Richard 1988. Materials for communicative language teaching and learning. - Annual Review of Applied Linguistics, 8, 140-163.

Saar, Merike; Meeri Sild 2008. All the World's a Puzzle: Form 10. Tallinn: Saar Graafika.

Sercu, Lies 2000. Acquiring Intercultural Communicative Competence from Textbooks. Leuven: Leuven University Press.

Sheldon, Leslie E. 1988. Evaluating ELT textbooks and materials. - ELT Journal 42(4), 237-246.

Shin, Jeeyoung; Zohreh R. Eslami; Wen-Chun Chen 2011. Presentation of local and international culture in current English language teaching textbooks. - Language, Culture and Curriculum, 3, 253-268.

Skopinskaja, Liljana 2003. The role of culture in foreign language teaching materials: an evaluation from an intercultural perspective. - Incorporating Intercultural Communicative Competence in Language Teacher Education. Ed. Ildikó Lázár. Strasbourg: Council of Europe Publishing, $39-68$.

Sleeter, Christine E.; Carl A. Grant 2011. Race, class, gender, and disability in current textbooks. - The Textbook as Discourse. Eds. Eugene F. Provenzo Jr, Annis N. Shaver, Manuel Bello. New York: NY Routledge, $183-214$.

Tomlinson, Brian (ed.) 2003. Developing Materials for Language Teaching. London, New York: Continuum.

Ur, Penny 2005. A Course in Language Teaching: Practice and Theory. Cambridge: Cambridge University Press.

Virsa, Raimond 2016. Teaching Culture Through English Language Coursebooks. MA thesis. Tallinn: Tallinn University.

Wallace, Catherine 2002. Local literacies and global literacy. - Globalisation and Language Teaching. Eds. David Block, Deborah Cameron, London: Routledge, 101-114.

Waters, Alan 2009. Advances in materials design. - The Handbook of Language Teaching. Eds. Michael H. Long, Catherine J. Doughty. Chichester, West Sussex: Wiley-Blackwell, 311-326. 
Yakhontova, Tatyana 2001. Textbooks, contexts and learners. - English for Specific Purposes 20(1), 397-415.

Yamada, Mieko 2010. English as a multicultural language: Implications from a study of Japan's junior high schools' English language textbooks. Journal of Multilingual and Multicultural Development 31(5), 491-505. Yamada, Mieko 2011. Awareness of race and ethnic diversity in Japan's junior high schools' English language textbooks. - Critical Inquiry in Language Studies: An International Journal 8(3), 289-312. 
RESÜMEE

\section{KULTUURIDEVAHELISE SUHTLUSPÄDEVUSE ARENDAMISE ANALÜÜS KAHES EESTI KESKKOOLIS KASUTATAVAS INGLISE KEELE KUI VÕÕRKEELE ÕPIKUS}

Artikli eesmärk on anda võrdlev hinnang kahele eesti keskkoolides kasutatavale inglise keele kui võõrkeele õpikule - eesti autorite koostatud õpikule All the World's a Puzzle. Form 10 ja rahvusvahelisele õpikule Activate B1+ Students' Book.

Töö teoreetilises osas antakse ülevaade kultuuri ja keele seostest, vaadeldakse lähemalt kultuuri rolli inglise keele õpetamisel, st sotsiaalsete ja kultuuriliste väärtushinnangute osatähtsust kultuurilise mitmekesisuse tundmaõppimisel inglise keele tundides, ja analüüsitakse keeleõpikute hindamise kriteeriume. Kultuuri vaadeldakse kui teadmiste, teadmiste tõlgenduste ja taasloome, kriitilise eneseanalüüsi ja konkurentsi pidevalt muutuvat kompleksi, mida on keelest kui arbitraarsest ja abstraktsest süsteemist keeruline eraldi vaadelda. Kultuur annab keelele konteksti, kus keel omandab tähenduse, ja keel vastavalt kultuurile vormi tähenduste aktualiseerumiseks. Kultuuriline pädevus hõlmab autorite hinnangul nii teadlikkust õppija lähte- ja sihtkultuurist kui ka võimet mõlemat kriitiliselt analüüsida ning adekvaatselt üksteisele vahendada.

Empiirilises osas hinnatakse võrdlevalt õpikutes kajastuvaid kultuuriteemasid, sotsiaalseid ja kultuurilisi väärtushinnanguid kindlaks määratud kriteeriumide alusel. Võrdlev analüüs põhineb taani teadlase Karen Risageri koostatud õpikute kultuurilise aspekti hindamiskriteeriumidel.

Töö tulemusena selgus, et kohalike autorite koostatud õpikus kajastuvad sotsiaalsed ja kultuurilised väärtushinnangud on üldjoontes kooskõlas ühiskonnas käibivate normide ja väärtus- 
hinnangutega. Rahvusvaheline õpik aga keskendub Anglo-Ameerika kultuuri propageerimisele ja rahvusvahelisteks inglise keele eksamiteks ettevalmistumisele. Lähtekultuure ignoreeritakse ja õpiku sihtgruppi (kogu maailma teismelisi) käsitletakse kui homogeenset gruppi, keda juhendatakse ilma kriitilisi küsimusi esitamata omaks võtma sihtkultuuri ja keelt ning Anglo-Ameerika ideaalse palgatöötaja identiteeti. Seetõttu saab õpikut vaadelda pigem keeleeksamiks ja globaalse töövõtja rolliks treeningu vahendina kui kultuurilise pädevuse õpetamise materjalina.

Võtmesõnad: keele ja kultuuri õpe, kohalikud ja globaalsed õpikud, inglise keel võõrkeelena 